Later chapters deal with routes by which radioactivity enters the food both from terrestrial and marine sources. Separate consideration is given to radioactive forms of strontium, caesium and iodine in their passage from soil to plant to man, and special reference is made to the change in the environmental distribution of radioactivity in successive croppings of an edible plant.

The book is divided into five more or less self contained parts each provided with a fairly extensive bibliography. This makes for easy reference to a particular topic but does involve repetition of certain basic information which has added materially to the length of the work. As a book of reference on this subject, it is almost unique and must provide an important source of information to those concerned with environmental contamination and associated problems. The basic material of the volume, provided by eight contributors, is the result of joint investigations by chemists and physicists as well as agricultural and biological scientists. It is another fascinating example of a team enterprise. G. E. Harrison

\section{WHERE PLANTS COME FROM}

\section{The Origin of Cultivated Plants}

By Franz Schwanitz. Pp. vi + 175. (Cambridge, Mass.: Harvard University Press; London: Oxford University Press, 1966.) 38s. net.

THE origin of cultivated plants has proved a more and more fruitful problem with the application of experimental methods. Breeding, chromosome studies and archaeology have converged in helping us to understand both crop origins and human applications. This book is not, however, concerned with such far-flung enquiries. Rather, it offers a popular discussion of the improvement of crops by selective breeding. These are well illustrated by photographs and diagrams. But the explanations are loose, often unauthenticated and sometimes irresponsible. The author is German, but he fails to mention the most illuminating of all German ideas on domestication-Engelbrecht's study of unconscious selection (in 1916). He does refer, however, to the mythical or comical achievements of Burbank and Michurin. And, as for his chromosomes, did he really see such things ? The publishers may be said to be also somewhat irresponsible. For Harvard University has been the home of some of the most notable contributors to this subject--East, Sax and Mangelsdorf, for example. In view of this record, the press of the university might have taken more care of its reputation.

C. D. DarLington

\section{RADIOACTIVE SOIL}

\section{Radioactive Contamination of Soil and Plants}

By R. M. Aleksakhin. Translated from the Russian by N. Kaner et al. Edited by S. Alexander. Pp. iv +108 . (Jerusalem: Israel Program for Scientific Translations; London: Oldbourne Press, 1965.) 47s.

Although this book claims to review all data accumulated to date, the delay caused by the publication in Moscow in 1963 , and translation and re-publication in Israel in 1965, means that the data quoted refer to nuclear tests to the end of 1961 with added information from 1962 .

On the whole the translation of the Russian book is well done and makes interesting reading. The few minor mistakes in the choice of the correct English equivalent are of little consequence. Spelling is good with one or two exceptions (such as "Scott Russel"). A transcription mistake on p. 49 refers to 16 per cent strontium-90 (presumably $16 \times 145,000 \mathrm{c} . / 100 \mathrm{ml}$.). The use of subheadings within the chapters would have improved the reading.
The first part deals with the nature and properties of radionuclides, the nature of fallout and its distribution on the surface of the Earth after various types of nuclear explosion. The effects of radiation on plant tissues are mentioned briefly, but the dose rate quoted from 1 ne. only should have referred to alpha-activity rather than to average fallout.

The next chapter has a misleading title "The Uptake of Fission Fragments by Plants ... " dealing almost exclusively with strontium and caesium with only occasional reference to others. Iodine is badly neglected. The bulk of the data given is familiar to those who have read reports by the United Nations and the Agricultural Research Council. Considerable emphasis is placed on the validity of strontium and caesium units, but this is by now old news. A very useful feature in this chapter, and indeed in the whole of the book, is the large amount of factual information presented in an orderly manner together with references to its origin.

In the remainder of the book the main theme is that the soil is the chief competitor for radionuclides in solution thereby restricting uptake by plants. Ways of restricting uptake of fallout by plants are then reviewed, and particularly ploughing, the use of lime, potassium salts, fertilizers and chemicals. The radioactive contents of various foods are quoted, some quito uselessly in counts per second $\begin{array}{ll}\text { rather than in pico-curies. } & \text { D. C. PICkering }\end{array}$

\section{PLANT EVOLUTION}

\section{An Evolutionary Survey of the Plant Kingdom}

By Robert F. Scagel, Robert J. Bandoni, Glenn E. Rouse, W. B. Schofield, Janet R. Stein and T. M. C. Taylor. Pp. xi +658 . (London and Glasgow: Blackie and Son, Ltd., 1966.) $80 s$.

THE reader who takes at their face value the title of this book and the statement inside the jacket that "this contemporary view of morphology . . . emphasizes evolutionary trends" is likely to be disappointed. Although it presents a thorough survey of the plant kingdom, equally divided between vascular and non-vascular plants, there is no more evolutionary emphasis than is to be found in many text-books of botany.

The short paragraphs at the end of some sections rarely do more than state evolutionary possibilities, with no attempt at discussion or the appraisal of theories. The evolution of the seed habit is dealt with in half a page; we are told that the authors feel that Thompson has presented a good case for its homosporous origin, but are given no indication of the arguments on which his case is based. Fortunately, the book includes excellent reference lists by means of which such topies may be more adequately pursued.

If one forgets evolution and considers this as a book about plant morphology and reproduction, it is more satisfying. It describes a large number of types, living and fossil, well distributed through the plant kingdom. It is very well illustrated, but the concentrated text is not easy to read. It is a useful book to have available to students for reference, and will be helpful to univorsity teachers faced with the need to lecture on plant groups with which they are not too familiar. J. L. Crosiry

\section{CACTI}

\section{Das Kakteenlexikon}

Enumeratio Diagnostica Cactacearum. By Curt Backeberg. Pp. 741. (Jena: Veb Gustav Fischer Verlag, 1966.) $48 \mathrm{MDN} ; 81 s .9 d$.

AfTER the completion of the six volume monograph Die Cactaceae (see Nature, 196,$871 ; 1962$ ) it was an excellent idea to produce this single volume digest more suited to 